\title{
Baseline Evaluation of Background lonising Radiation in Cocoa Plantation in Uyo, Akwalbom State, Nigeria
}

\author{
Essien I. E. , Nyong A. B., Akankpo A. O., Ekott E. E., Umoh U. A., Inyang A. J. \\ Department of Physics, University of Uyo, Uyo, Nigeria \\ Email address: \\ imeessien27@yahoo.com (Essien I. E.) \\ ${ }^{*}$ Corresponding author \\ To cite this article: \\ Essien I. E., Nyong A. B., Akankpo A. O., Ekott E. E., Umoh U. A., Inyang A. J. Baseline Evaluation of Background Ionising Radiation in \\ Cocoa Plantation in Uyo, AkwaIbom State, Nigeria .Radiation Science and Technology. Vol. 3, No. 2, 2017, pp. 13-17. \\ doi: $10.11648 /$ j.rst.20170302.13
}

Received: January 5, 2017; Accepted: January 19, 2017; Published: April 26, 2017

\begin{abstract}
Radionuclides are found in different media including, soils, air, water, plants, vegetables, and in fruits etc. These radionuclides and their isotopes contaminate the environmentand could cause deleterious effect on human beings when ingested or inhaled. The cocoa plantation is a new plantation developed two years ago in the State for resource management and enhanced cocoa production. In situ measurement of the background ionising radiation was conducted with Radex (1212) radiation survey meterwhich measured background ionising radiation level in micro Seviert per hour. The measured values were converted to annual equivalent dose rate and annual effective dose. The mean background ionizing radiation (BIR) measured was obtained as $0.083 \mu \mathrm{Sv} / \mathrm{hr}$ and a mean annual BIR of $0.727 \mathrm{mSv} / \mathrm{yr}$. The obtained mean annual BIR obtained is lower than the worldwide BIRof $2.4 \mathrm{mSv} / \mathrm{yr}$. The annual equivalent dose rate of radiation obtained in the plantation was ranged between 0.1261 to $0.2067 \mathrm{mSv} / \mathrm{yr}$ with a mean value of $0.1454 \mathrm{mSv} / \mathrm{yr}$. The mean annual effective dose was $0.1015 \mathrm{mSv} / \mathrm{yr}$ and lower than the recommended $1 \mathrm{mSv} / \mathrm{yr}$ as a safety limit for the public. Therefore regulatory controls are not necessary for now as this is a new plantation.
\end{abstract}

Keywords: Background Ionising Radiation, Annual Equivalent Dose Rate, Annual Effective Dose Cocoa, NORM, Radionuclides

\section{Introduction}

Our environment is known to be continuously bombarded with ionising radiation from terrestrial and artificial sources, with its effect on human beings and environment as it continuously interact with it. The terrestrial sources are rocks, soils, plants, water and air and vegetations [1].The naturally occurring radioactive material (NORM) found in soils and rocks are mostly ${ }^{40} \mathrm{~K},{ }^{235} \mathrm{Th},{ }^{238}$ Uand ${ }^{228} \mathrm{Ra}$ and their associated radioisotopes. The artificial sources include medical for diagnostic and oncology purposes and industrial sources [2]. The radioisotopes found in the soils are transferred to the surface of the soil through human activities like mining, cultivation of the soil and consequently radiating ionising radiation to the environment. Itis obvious that radionuclides found in the surface of soils could also be transferred to the soil through infiltration process thus changing the chemical and physical processes of the soil [3] and could also be transferred to plants which act as one of the paths through which radioactivity and radiation get to man.

It is also established from various studies that these NORM are also present in building materials such as, stones, sand, gravel, cement, concrete, brick, tiles, wood, gypsum, granites etc [4, 5], clay soils an driver sediments [6, 7] established that vegetation contains traces of radionuclides and even in timbers [9]. It is known that these NORMs and heavy metals in the soils contaminates the soils, environment and plants on these soils as the plants uptake these radionuclides and the heavy metals $[10,11]$. Natural radioactivity concentration have been measured in vegetables, fruit, medicinal plants and its associated committed effective dose due the ingestion of the plants also determined [12].

It is known that an uncontrolled dose of background ionizing radiation (BIR) when interacting with human beings could have deleterious effect as the radiation combines with the deoxyribonuclide acid (DNA) in the blood thus producing 
free radicals. The resulting free radical causes changes in the chemical bonds of the body thus causing biological effect with a resulting cancerous effect.

In some parts of Nigeria, a number of authors have reported measurements of gamma radiation exposure levels from soils, building materials, dumpsites in Akwalbom State, Nigeriaetc, as seen in the literatures $[13,14]$ but none is reported for a cocoa plantation, therefore this necessitated this study. In view of the effect of BIR on humans this study is conducted as a baseline survey data for the plantation as it is new and also expected to serve the public as a research farm for a long time.

\section{Materials and Method}

\subsection{Study Site}

The cocoa plantation considered for the investigation is located at Ekpemiong Itak along Uyo- Ikot Ekpene Road, Akwalbom State (Lat. 5'5' 42.2' N, Long. 7०50 '57.9' $\mathrm{E}$ and $89 \mathrm{~m}$ altitude. The Cocoa plantation in Akwalbom State of Nigeria was established in 2015 with the mandate to conduct research into genetic improvement and production of Cocoa, its overall farming system and resource management. The plantation was divided into 20 locations evenly spaced at $20 \mathrm{~m}$ between locations for easier coverage.

\subsection{Exposure Measurement}

In situ measurement of the background ionizing radiation (BIR) level was carried out using Radex (RD 1212) radiation meter which measured ionising radiation level rate in micro Sievert per hour $(\mu \mathrm{Sv} / \mathrm{h})$. The meter is a handheld digital radiation detector which detects gamma radiation, $\mathrm{X}$ radiation and beta radiations with a dose power range of 0.05 to $999 \mu S v / h$ and a linear energy response to gamma radiation between 0.1 to $1.25 \mathrm{MeV}$. For effective monitoring, the radiation meter was placed at the gonad level of $1 \mathrm{~m}$ above ground level with the window of the meter directed toward each site and 10 readings taken in different directions in each site and the mean recorded. Measurements of exposure levels in this investigation were taken in the afternoon between 1000 hours and 1700 hours for effective response of the meter to environmental radiation exposures within Calabar [8]. The measured mean background ionising radiation $(\sigma)$ is converted to annual equivalent dose rate (HTc) using equation 1[15]

$$
H T_{C}(m S v / y r)=\sigma(\mu S v / h r) \times \mu \times 24 h r s \times 365 \text { days } \times Q \times 10^{-3}
$$

$\mathrm{Q}$ is the quality factor for the gamma radiation and has a value of unity and $\mu$ the outdoor occupancy factor with value 0.2

The annual effective dose (AED) from this exposure is obtained by multiplying the annual equivalent dose by 0.7 which is the conversion factor from equivalent dose to effective dose

\section{Results}

The plantation was divided into 20 locations and coded LT 01 - LT 20. The mean measured BIR, calculated annual equivalent dose rate and annual effective dose are presented in Table 1 .

Table 1. Mean BIR and annual equivalent dose rate.

\begin{tabular}{lllll}
\hline S/N & Location code & BIR $\sigma(\mu \boldsymbol{S v} / \boldsymbol{h r})$ & HT $(\mathbf{m S v} / \mathbf{y r})$ & AED $(\mathbf{m S v} / \mathbf{y r})$ \\
\hline 1 & LT01 & $0.118 \pm 0.001$ & 0.2067 & 0.1447 \\
2 & LT02 & $0.086 \pm 0.001$ & 0.1506 & 0.1054 \\
3 & LT03 & $0.077 \pm 0.002$ & 0.1349 & 0.0944 \\
4 & LT04 & $0.076 \pm 0.001$ & 0.1331 & 0.0932 \\
5 & LT05 & $0.074 \pm 0.001$ & 0.1296 & 0.0907 \\
6 & LT06 & $0.093 \pm 0.002$ & 0.1629 & 0.1140 \\
7 & LT07 & $0.078 \pm 0.002$ & 0.1366 & 0.0956 \\
8 & LT08 & $0.103 \pm 0.002$ & 0.1804 & 0.1263 \\
9 & LT09 & $0.076 \pm 0.002$ & 0.1331 & 0.0932 \\
10 & LT10 & $0.098 \pm 0.003$ & 0.1716 & 0.1201 \\
11 & LT11 & $0.083 \pm 0.003$ & 0.1454 & 0.1018 \\
12 & LT 12 & $0.076 \pm 0.002$ & 0.1331 & 0.0932 \\
13 & LT 13 & $0.090 \pm 0.003$ & 0.1576 & 0.1103 \\
14 & LT14 & $0.080 \pm 0.003$ & 0.1401 & 0.0981 \\
15 & LT15 & $0.074 \pm 0.001$ & 0.1296 & 0.0907 \\
16 & LT16 & $0.078 \pm 0.001$ & 0.1366 & 0.0956 \\
17 & LT 17 & $0.076 \pm 0.001$ & 0.1331 & 0.0932 \\
18 & LT18 & $0.072 \pm 0.001$ & 0.1261 & 0.0883 \\
19 & LT 19 & $0.072 \pm 0.001$ & 0.1261 & 0.0883 \\
20 & LT 20 & $0.075 \pm 0.001$ & 0.1314 & 0.0920 \\
& MEAN & $0.083 \pm 0.002$ & 0.1454 & 0.1015 \\
\hline
\end{tabular}

The background ionising radiation recorded in Table 1 shows an exposure range of $0.074 \pm 0.001$ to $0.118 \pm 0.001$ $\mu \mathrm{Sv} / \mathrm{h}$ with a mean value of $0.083 \pm 0.001 \mu \mathrm{Sv} / \mathrm{h}$ with the maximum value obtained from the main entrance into the plantation coded LT01. The range of annual equivalent dose rate for the exposure obtained in the plantation is between 0.1296 to $0.2067 \mathrm{mSv} / \mathrm{yr}$ with a mean of $0.1454 \mathrm{mSv} / \mathrm{yr}$ with a mean calculated annual effective dose of $0.1015 \mathrm{mSv} / \mathrm{yr}$

\section{Discussion}

The demonstration Cocoa plantation, Uyo was established two years ago has since been in operation undertaking the research into the improvement of the crop and resource improvement in the area of personnel capacity building. It is expected that the application of mechanized system of farming, tilling the soils, scrapping of the top soils will continuously bring out the NORMs accumulated in the soils. Again the addition of fertilizers and other additives to the soils are expected to contaminate the soils and could raise the background ionising radiation level of the environment [16]. Radiation health risk now has been of concern by public and they should know the hazard risks of the area there are visited. Therefore the knowledge of the level of background ionising radiation of an environment is necessary to provide information on the health risk due to the exposures to the occupants of the environment, workers and the public with the consequent guidance of the radiation regulators on possible remediation controls. 


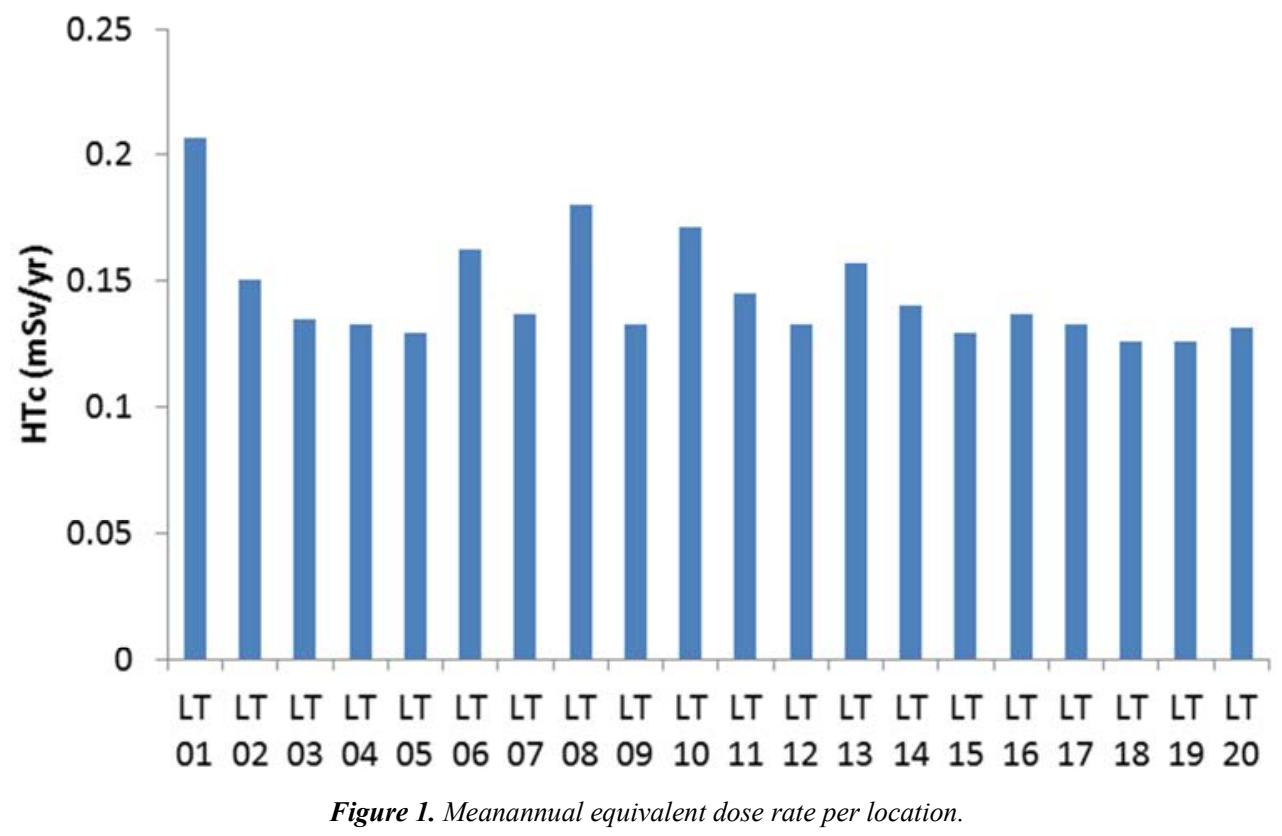

The mean annual equivalent dose per location (fig. 1) shows that LT 01 has the highest mean annual equivalent dose of $0.2067 \mathrm{mSv} / \mathrm{yr}$, this location is the entrance into the plantation which is closed the main road implying that other sources such as the vegetation, vehicular movement, and concrete buildings could have contributed to the high dose.
Other locations such as LT 06, LT 08 and LT 10 have high doses, at these locations there were abandoned heaped of cements and concretes which would have been used for construction of buildings. The mean annual BIR obtained for the plantation is $0.727 \mathrm{mSv} / \mathrm{yr}$ and is lower than the world wide annual BIR of $2.4 \mathrm{mSv} / \mathrm{yr}$ [17].

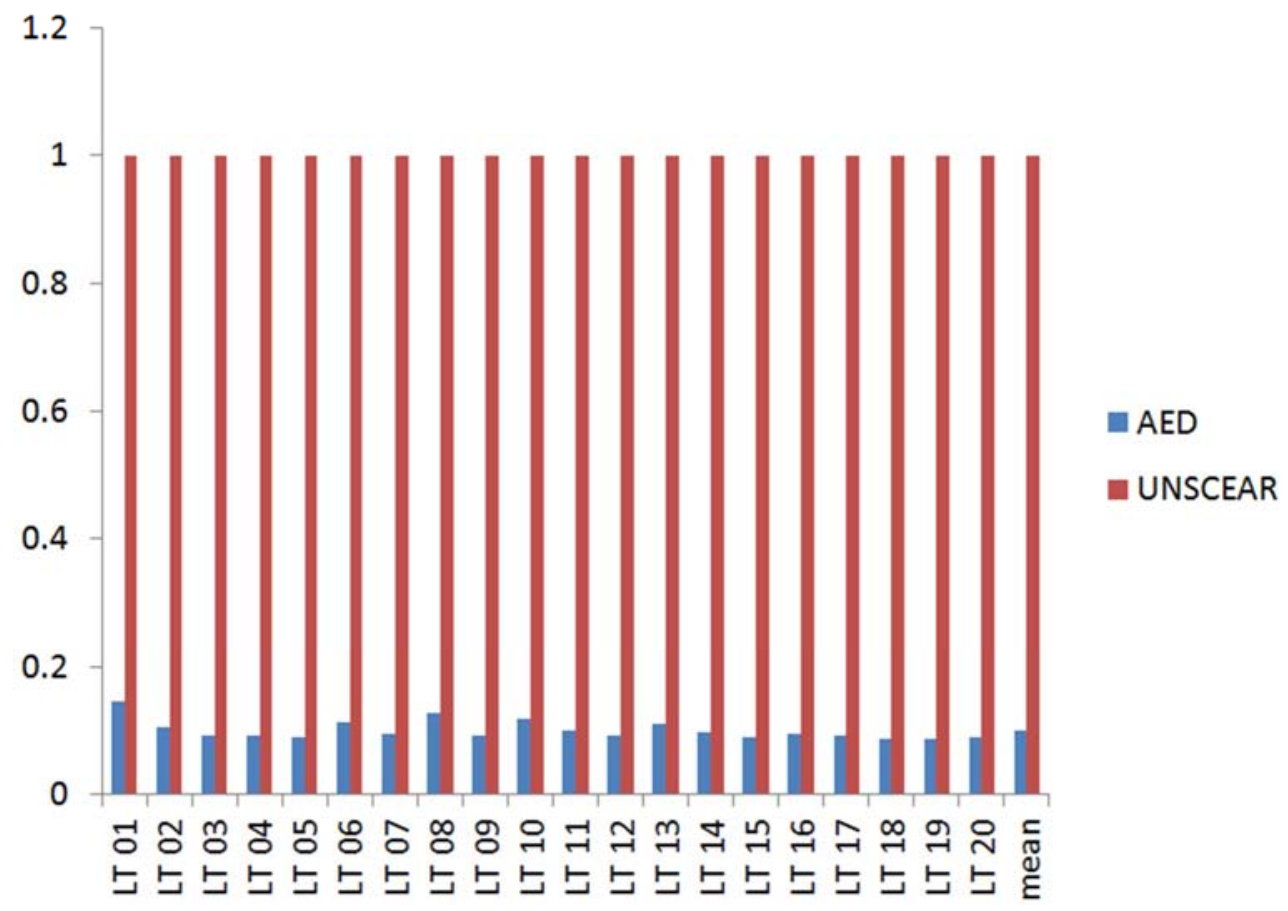

Figure 2. The comparison of annual effective dose with UNSCEAR standard.

The annual effective dose (AED) which indicates the occupational risk on the workers and occupants of the plantation was calculated and obtained as $0.1015 \mathrm{mSv} / \mathrm{yrand}$ compared with the United Nations Scientific Committee on the effects of Atomic Radiations Sources and Effect of Ionising Radiation [1] standard and the results show that the exposure level in the plantation is lower than the $0.3-1$ $\mathrm{mSv} / \mathrm{yr}$ safety limit as prescribed by for the public (Fig. 2). The mean AED obtained for the plantation islower than the mean AED of $0.17 \mathrm{mSv} / \mathrm{yr}$ obtained for the central dumpsites in Uyo, Akwalbom State [13] but higher than the mean AED of $0.095 \mathrm{mSv} / \mathrm{yr}$ obtained for the central 
mechanic village in Uyo AkwaIbom State [19]. The comparison of the mean AED obtained for this study with another study within the locality of Itu Local government area in the state showsthat the AED in this studyis higher than $0.0614 \mathrm{mSv} / \mathrm{yr}, 0.0365 \mathrm{mSv} / \mathrm{yr}$ and $0.0933 \mathrm{mSv} / \mathrm{yr}$ obtained for Ayadehe, Oku Iboku and Ntak Inyang respectively [19]. This variation in the dose per the study areas within the same state could be due to the difference in the geology of these areas. The result is also an indication of a negligible potential health risk due to the exposures in this plantation as there is no low level radiation without health risk when interacted with for a long time. It is expected that in a long run there might be a rise in the radiation level resulting from prolong activities in the soil and the addition of fertilizers and other additives. Therefore, there is need for the administrators of the plantation to set up a regulatory advisor unit to ensure that the personnel and staff working in this plantation spend fewer periods in the long run as the plantation increases it production. The probable control measure is that workers should spend fewer periods in the plantation, probably 60 hours a week throughout 50 weeks in a year in order to limit the exposure level on the worker and lowers the probability of them having ionising radiation related cancers [20] and the workers should not be allowed to spend their 70 years in the plantation, this lowers the probability of excess lifetime cancer risk. Thirdly the source and type of the fertilizer both organic and inorganic and any other additive should be regulated to avoid excessive addition of the radioisotopes to the already contaminated soil.

\section{Conclusions}

The Cocoa plantation is a government owned plantation and shall save as a research farm. The measurement of background ionizing radiation was conducted as a baseline data necessary to help monitor the rise of the background ionising radiation level in the plantation to guard the workers against the potential health risk due to the exposures. The results for this study show that the mean background ionising radiation obtained from this work was below the mean worldwide value of $2.4 \mathrm{mSv} / \mathrm{yr}$ while the annual effective dose rate was lower than the recommended acceptable safe limits of $1 \mathrm{mSv} / \mathrm{yr}$ for the public. This indicates that there is no potential health risk for workers who work there for now but accumulative effect should be avoided.

\section{References}

[1] UNSCEAR (2000). United Nations Scientific Committee on the effects of Atomic Radiations Sources and Effect of Ionising Radiation, New York

[2] Essien, I. E, Inyang S. O and Egbe, N. O (2016). Entrance Surface Air Kerma during Skull, Abdomen and Pelvis X-ray Examinations in Diagnostic Radiology Facilities in Akwalbom State. Radiation Science and Technology, 2(1): 612 .
[3] Taskin, H.M, Karavus, P., Touzogh, S., Hindiroglu and Karaham, G., (2009): Radionuclide concentration in soil and lifetime cancer risk due to the gamma radioactivity in Kirklareli, Turkey. Journal of environmental radioactivity, 100: 49-50.

[4] Alharbi, W. R., Alzahrani, J. H., and Abbady, A. G. (2011): Assessment of radiation hazards indices from granite rocks of Southern Arabian shield, Kingdom of Saudi Arabia, Australian Journal of Basic and Applied Sciences, 5(6): 672-682.

[5] Akhtar, N., Tufail, M and Ashraf, M (2005): Natural environmental radioactivity and estimation of radiation exposure for saline soils. International journal of environmental Sciences and technology, 1(4), 279-285.

[6] Ramasamy, V., Suresh, G., Meenakshisundaram, V. and Gajendran V (2009): Evaluation of Natural Radionuclide Content in River Sediments and Excess Lifetime Cancer Risk Due to Gamma Radioactivity. Research journal of environmental and earth sciences 1(1): 6-10.

[7] Akinloye,M..K., Olomo J. B. (2005): The Radioactivity in some Grasses in Environment of Nuclear Research Facilities located within the Obafemi Awolowo University, Ile-Ife, Nigeria. Nigerian Journal of Physics. 17: 219-225.

[8] Inyang, S. O., Inyang, I. S and Egbe, N. O. (2009): Radiation Exposure Levels within Timber Industries in Calabar, Nigeria. Journal of medical Physics. 34(2): 97-100.

[9] Chibowski, S (2000). Studies of Radioactive Contaminations and Heavy Metal Contents in Vegetables and Fruit from Lublin, Poland. Polish Journal of Environmental Studies. 9(4) 249-253.

[10] Poursharifl Zahra, Ali Ebrahiminia, Mohsen Asadinezhad, Abolfazl Nickfarjam, Abolghasem Haeri and Karim Khoshgard (2015). Determination of Radionuclide Concentration in Tea Samples Cultivated in Guilan Province, Iran. Iran Journal of medical Physics, 12(4); 271.

[11] Harb, S (2015). Natural Radioactivity Concentration and Annual Effective Dose in Selected Vegetables and Fruits. Journal of Nuclear and Particle Physics, 5(3): 70-73.

[12] Chandrashekera, K and Smasshekarappa, H. M, (2016). Estimation of radionuclides concentration and average annual committed effective dose due to ingestion from selected medicinal plants of south India. Journal of Radiation Research and Applied Sciences. 9; 68-77.

[13] Essien, I. E and Essiett, A. A (2016): Investigation of radiological Hazards Indices within Uyo Metropolis Central Dumpsites, Akwalbom State, Nigeria, International Journal of Scientific Research Publications, 6(5); 687-691.

[14] Inyang, S. O., Essien, I. E and Egbe, N. O. (2016):Exposure levels within building materials shops in Calabar, Cross River State, Nigeria. Journal of Applied Physical Sciences International. 7(1): 12-17.

[15] Etuk, S. E., George, N. J, Essien, I. E. and Nwokolo, S. C (2015). Assessment of radiation exposure levels within Ikot Akpaden Campus of Akwalbom State University, Nigeria. IOSR Journal of Applied Physics 7(3): 86-91.

[16] Diab, H. M., Nouh, S. A, Hamdy, A., EL-Fiki, S. A.(2008). Evaluation of Natural Radioactivity in a Cultivated Area around a Fertilizer Factory. Journal of Nuclear and Radiation Physics, 3(1): 53-62. 
[17] Avwiri, G.O and Olatubosun, S. A (2014).Assessment of environmental radioactivity in selected dumpsites in Port Harcout, River state, Nigeria. International journal of scientific and technological research, 3 (4) 263-269.

[18] Essien, I. E., and Umoh, U. A (2016). Measurement of Background Radiation Level from Central Automobile Mechanic Village, Akwalbom State, Nigeria. Journal of Basic and Applied Research International 18(1): 36-39.

[19] Essien I. E and Akpan, E. N (2016):Evaluation of
Radiological Hazards Indices Due to Radioactivity in Quarry Sites in Itu, AkwaIbom State, Nigeria. International Journal of Scientific Research in Environmental Sciences, 4(3): 00710077.

[20] Jibiri, N. N and Obarhua. (2013). Indoor and outdoor gamma dose rate exposure levels in major commercial building materials distribution outlets and their radiological implication to occupants in Ibadan, Nigeria; Journal of natural sciences research, 25-31. 